adrenals, epididymal fat, perirenal fat and body weight. Testosterone propionate and progesterone caused no change in plasma lipid levels. Norethynodrel (17 $\alpha$-Ethynyl-17 $\beta$-hydroxy-5(10)-estren-3-one) produced the decrease of plasma cholesterol with similar pattern to that caused by the stilben-type of estrogen. Cortisol acetate produced the increase of both cholesterol and phospholipid level in the similar experiment. Discrepancies appeared in the previous reports of other workers on the estrogen effect on rat plasma cholesterol were discussed and somewhat resolved with our results.

\title{
Influence of the Thyrotropic Hormone on Active Peroxidase of the Thyroid Gland
}

\section{Takeshi NIIYA}

Department of Obstetrics and Gynecology, Kobe Medical College (Director : Prof. Yasuo Ueda)

An attempt was made by the author to devise a new method of determining the active peroxidase of thyroid gland by modified Randall's method of determining active peroxidase, by adding K.I. \& 1-tyrosine to a substrate and by evaluating the rate of $\mathrm{H}_{2} \mathrm{O}_{2}$ loss with use of Warburg's manometer and through ${ }_{-}^{-}$which variation of the amino iodides could be traced.

By means of the manometric method, the influence of TSH on peroxidase was examined by adding TSH to the substrate and paperchromatographically tested of the reacted solution.

The following results were obtained upon analysis of the formed substances:

1. TSH directly accelerates activation of peroxidase.

2. No specific character could be observed whether peroxidases are from vegetative or animal sources on the oxidation process of the iodides based on the fact that they are equally activated in the presence of TSH $10^{-2}-10^{-3}-10^{-4}$ J.S.U., whether standard product of peroxidase employed, or tried with the thyroid homogenate of guinea pigs.

3. Direct relationship has been shown between the concentrated $\mathrm{TSH}$ and the rate of increased activity in TSH concentration range of $10^{-2}-10^{-3}-10^{-4} \mathrm{~J} . \mathrm{S} . \mathrm{U}$.

4. Paperchromatographic examination of solution with the standard peroxidase revealed the fact that formotion of monoiodotyrosine and diiodotyrosine at TSH $10^{-2}$ J.S.U. was most increased, and the rate of amino iodide decrease was noted in the order of TSH $10^{-2-} 10^{-3}-10^{-4} \mathrm{~J} . \mathrm{S} . \mathrm{U}$. The formation of both monoiodotyrosine and diiodotyrosine was observed with the thyroid homogenate of male guinea pigs also.

5. It is assumed that increased formation of amino iodides was due to activation of peroxidase by TSH which in turn seems to accelerate oxidation of iodide and the other iodizing processes. 


\title{
甲状腺 Peroxidase 活性に及ぼす甲状腺刺戟
}

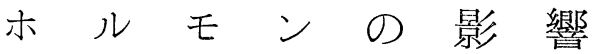

\author{
神戸医科大学产婦人科教室 (指導 植田安雄教授)
}

新谷毅

（昭和 38 年 1 月 10 日受付)

緒 論

Peroxidase は $\mathrm{H}_{2} \mathrm{O}_{2}$ を分解し，その際発生機酸素を生じ，生体内の酸化過程に関与する醳素である.

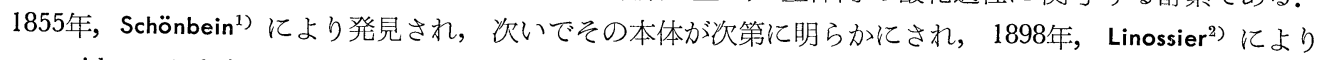
peroxidase と命名され，更に Raundniz ${ }^{3}$ ， Loew $\left.{ }^{4}\right)$ とり，同じく生体酸化還元過程に関与する catalase とは異る酵素である事が明らかにされた。 その後, Willstätrer ${ }^{5)}$ は, 活性測定法を考案し, それを利用して 吸着法により西洋ワサビの peroxidase の精製を試み, かなり高純度のものを分離し得た。更に1941年, Theorel1 $1^{6)}$ は，ワサビを処理して peroxidase の結晶化に成功した。次いで乳汁中の peroxidase も結晶化 され，又，Agner 勇により白血球中の peroxidase る精製分雄された，動物性 peroxidase としては，上述 の牛乳と白血球に由来するものか知られていたが, 近年, その他の藏器, 即ち, 肝臓, 子宮, 棰液腺, 甲状 腺等の中にも，peroxidase の存在する事が発見された，此，peroxidase は，生体内酸化の終末に於て発生 する細胞毒である $\mathrm{H}_{2} \mathrm{O}_{2}$ を消滅させ, 細胞を $\mathrm{H}_{2} \mathrm{O}_{2}$ の害から保護すると共に, 酸素消費の節約に役立つと 考朰れていた。 しかしながらその後の研究により，細胞中に存在すると予想される $\mathrm{H}_{2} \mathrm{O}_{2}$ を分解するに 必要な量よりも，遙かに多量の peroxidase が，特に甲状腺細胞内に存在する事が明らかにされた。沃度代 謝に重要な意義を持つ甲状腺に於て，ての peroxidase が，甲状腺ホルモン合成の第一段階たる沃度イオン 酸化に関与する事はほぼ確実とされている。即ち，1943年，Dempsey ${ }^{8)}$ が甲状腺滤胞中に peroxidase の存 の在を暗示する組織化学的研究を発表して以来, De Robertis ${ }^{99}$ \&. Grasso, Rosenberg ${ }^{10)}$, Alexander ${ }^{11}$ ， De Groot $^{12)}$ \& Davis 等によりその存在が確められている。乙れらの peroxidase は，上述の沃度イオンの酸化 の他に，更に酸化的 thyroxine 縮合にも関与すると云われている.

一方，甲状腺刺战ホルモン（以下 TSH と略記する）は，甲状腺に於ける沃度代謝の各段階に於て，促 進的に作用するものとされている，従つて甲状腺に於て沃度イオンの酸化に関与する，此の peroxidase と TSH との間に, 何等かの関連のある事が予想される。1946年, De Robertis ${ }^{9}$ は, 組織化学的研究で, TSH が甲状腺 peroxidase 活性を增強させると記載したのみで，その他には見るべき業蹟がない，従つて，両者 の関係を生化学的に解明する事は，極めて重要な意義を持っている.

処で，従来の peroxidase 活性測定法では，peroxidase 活性そのものは測定し得るが，その際の沃度代謝 の状態を検討する事が出来なかつた。にてで著者は，peroxidase 活性を manometry で測定し，同時に沃 度アそノ酸の定量をも検討し得る新法を案出し，ての方法によりてれらの問題を検討した。

第一章「Warburg 検圧計による peroxidase 活性の新测定法」

まえがき

従来より peroxidase の活性測定法には, Purpurogallin 法 ${ }^{5}$, Guajacol 法 $^{13)}$, Ettori 検圧法 ${ }^{14}$, Randall 第38巻 第11号 
法 ${ }^{15}$ )等がある. Purpurogallin 法, 及び guajacol 法は, 夫々基質として, pyrogallol, 及び guajacol を用 い, それに $\mathrm{H}_{2} \mathrm{O}_{2}$ と酵素液を作用させ, 酸化生成物 purpurogallin, 又は tetraguajacol を比色して peroxidase の活性を測定する方法で, 以上の二つは比色法 (colorimetry) であるが, 次の Ettori 検圧法, 及 び Randall 法は, Warburg 検圧計を用いる gasmetry である. 即ち, Ettori 法は, 基質として pyrogallol を用い，それに $\mathrm{H}_{2} \mathrm{O}_{2}$, 酵素液を加えると， purpurogallin，水， $\mathrm{CO}_{2}$ を生ずるが，乙の $\mathrm{CO}_{2}$ 発生量を， peroxidase 活性の示標とした. 又, Randall 法は，基質として p-amino 安息香酸を用い，それに $\mathrm{H}_{2} \mathrm{O}_{2}$. 酸素液を加え, その際生ずる発生機酸素の p-amino 安息香酸酸化への利用率を Warburg 検圧計により求 め, 之を以て peroxidase 活性としている方法である.てれ等は何れも基質に pyrogallol, guajacol, p-amino 安息香酸を使用するのみで，その反応系に沃度化合物を含んでいない為に，その際の沃度代謝の推移を検討 する事は不可能である，そてで著者は，Randall 法を改良して，基質として KI，及び l-tyrosine を用い， peroxidase が沃度イオンの酸化に利用した発生機酸素量を Warburg 検圧計で測定して, peroxidase の活 性值を求めると共に, その際の沃度ア之, 酸生成過程をも同時に究明し得る様考案した. 先ず本章に於て は，此測定法の基礎的な実験条件を検討し，その至適条件を決定し，次いで Ettori 法を追試し，本法と Ettori 法との優劣を比較した.

\section{実験材料並びに方法}

\section{I 実験材料}

1) peroxidase 源として，標品 peroxidase (horse radish peroxidase) とモルモット甲状腺を用いた.

a) 標品 peroxidase

標品 peroxidase は, 関東化学株式会社製の力価60単位/ $1 \mathrm{mg}$ ののを, 生理的食塩水に溶かし 1 容器当 り 50 使用した.

b) モルモット甲状腺 homogenate は，生後 3 カ月の体重 $400 \mathrm{~g}$ 前後の雄モルモット15匹を，エーテル麻 酔下で屠殺後, 直ちにその甲状腺を採取して, pH 7.4 の Krebs-Ringer's bicarbonate 液に浸して, 充分 に血液を洗滌し, 滤紙上で脂肪, 結合織等の不純物を除去した後に, 滤紙にて脱水, 直ちに torsion balance で科量し，氷冷しながう金属 homogenizer で30秒間 3 回処理し，甲状腺組織 homogenate を作製し，て れを10\%の割に Krebs-Ringer's bicarbonate 液に混和した. 実験は, 屠殺後 2 時間以内に行う事とし，そ の間 homogenate $44^{\circ} \mathrm{C}$ 亿保存した。 モルモットを用いたのは，TSH への感受性が高いと云う Bergmann ${ }^{16)}$ の意見に従つたのである. 又, 性周期の影響のない雄を釈んだ.

2) Catalase は，関東化学株式会社製のもので，牛の肝蔵より作製され，力価は，1200-1400K.U. であ る.

3) medium としては, Krebs-Ringer's bicarbonate 液を stock solution よりその都度調製し, pH 7.4 として使用した. TSH 活性は酸性側に於て低下すると云う望月 ${ }^{17)}$ の報告に従つて, TSH の溶媒の $\mathrm{pH}$ と して7.4を選んだ.

4) $\mathrm{H}_{2} \mathrm{O}_{2}$ (江戸川化学製) は, 1 容器当り種々の $\mu \mathrm{mol}$. を使用した.

5）基質としては，KI (和光製) を 1 容器当り $40 \mu \mathrm{mol}$. を用い, 更にてれに 1 容器当り $30 \mu \mathrm{mol} の$ 1-tyrosine (和光製) を添加した。

次いで Ettori 検圧法を行う為に，次のものを用意した。即ち，主室に 5\% pyrogaroll $0.2 \mathrm{ml}, 0.25 \%$ 燐酸塩（pH 6.0） $0.5 \mathrm{ml} ., 0.01 \mathrm{MH}_{2} \mathrm{O}_{2} 1.5 \mathrm{ml}$., を入れ，次いで第 1 側室に醳素溶液 $0.1 \mathrm{ml}$ 第 2 側室に $20 \%$ $\mathrm{H}_{2} \mathrm{SO}_{4}$ 0.5ml. (作用停止用) を入れた.

\section{II. 実験方法 \\ 1) 実験装置}

Warburg 検圧計と, 第 1 図の如き容器を使用した.

a) 先ず Fig.1 の主室には, 標品 peroxidase 50 , 又は10\%雄モルモット甲状腺 homogenate 浮遊液 第38巻 第 11 号 
$0.3 \mathrm{ml}$ (新鮮重量 $50 \mathrm{mg}$ ) 飞, 1 容器当り $\mathrm{KI}$ $40 \mu \mathrm{mol}$. と 1-tyrosine $30 \mu \mathrm{mol}$. を添加し た.

b ) 側室

i) 第 1 側室には, Krebs-Ringer's bicarbonate 液 $1.0 \mathrm{ml}$. 飞 $\mathrm{H}_{2} \mathrm{O}_{2}$ を夫々, 1,5 , 10，20，及び $30 \mu \mathrm{mol}$. 入れた.

ii）更に第 2 側室には, 一定時間peroxidase を作用させた際，残つている $\mathrm{H}_{2} \mathrm{O}_{2}$ を分解 する為に注加する catalase $10 \mathrm{mg}$. を含む生 理的食塩水 $0.5 \mathrm{ml}$. を入れた.

c) 副室

$\mathrm{CO}_{2}$ 吸収の目的で，20\%苛性カリ $0.2 \mathrm{ml}$ 濾紙と共に入れた。

\section{2) 実験操作}

peroxidase 活性の測定には, Warburg
Fig. 1. Vessels and Reaction mixture in it.

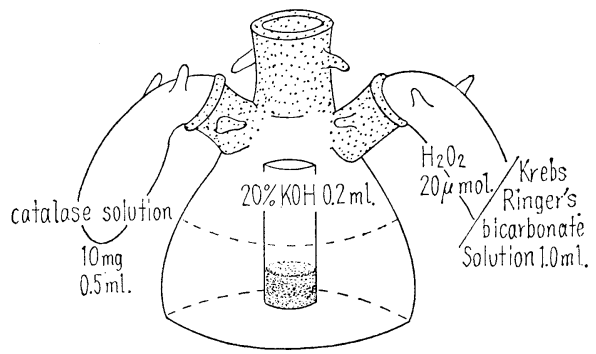

i) peroxidase solution $0.3 \mathrm{ml}$

horse radish

or $10 \%$ Thyroid homogenate of male guinea pig

ii) Krebs Ringer's bicarbonate solution $1.2 \mathrm{ml}$.

(l-tyrosine $30 \mu \mathrm{mol}$.

KI $40 \mu \mathrm{mol}$.

(TSH $10^{-1} \sim 10^{-4}$ J.S.U./vessel)

検圧計を用い，気相は空気とし，温度は $37.5^{\circ} \mathrm{C}$ に，通常毎分 100 田振盪した。先ず10分間予備振盪の後 に, 第 1 側室より $\mathrm{H}_{2} \mathrm{O}_{2}$ 溶液を加え, 一定時間振盪して $\mathrm{H}_{2} \mathrm{O}_{2}$ に peroxidase を反応せしめる. 一定時間の 後, 第 2 側室の catalase を加え，残つている $\mathrm{H}_{2} \mathrm{O}_{2}$ を分解して $\mathrm{O}_{2}$ を発生せしめ，分解遊離された酸素量 を manometer にて読みとる. (此值を A とする)。他方，別の容器で第 1 側室に同量の $\mathrm{H}_{2} \mathrm{O}_{2}$ と，第 2 側 室に同量の catalase とを入れたものを作り，同時間振盪した後，両者を混和し，その際発生した酸素量を manometer にて読みとる. (此值をWとする). 各容器により異る容器恒数 (flask constant) KをW，及びA に乗ずると，それぞれの酸素量 $(\mu l)$ が得られる。.Avogadro の法則によれば， $\mathrm{H}_{2} \mathrm{O}_{2} 1 \mu$ mol. よりの酸 素発生量は，標準状態にて $11.2 \mu l$ であるから，ての KW-KA の值 $(\mu l)$ を $11.2 \mu l$ にて除する事により $\mu \mathrm{mol}$. として表わし得る。乙れが peroxidase の沃度酸化利用酸素量 $\mathrm{X}$ ，即ち，peroxidase の活性測定值 である，なお甲状腺 homogenate に於ては，乾燥重量 $1 \mathrm{mg}$. 当りとする為，更に活性測定值を甲状腺乾燥 重量 $\mathrm{m}$ に除した. 即ち, 次式 $\mathrm{X}=\frac{\mathrm{KW}-\mathrm{KA}}{11.2} \times \frac{1}{\mathrm{~m}}$ にて peroxidase 活性測定值を表わし得る.

次に Ettori 法の実施に当つては，先ず $20^{\circ} \mathrm{C}$ の恒温槽にて 10 分間予備振盪を行つた後に閉栓し，第 1 側室 より醭素液を加え，5分後に $\mathrm{H}_{2} \mathrm{SO}_{4}$ を加え作用を停止せしめ，その時の $\mathrm{CO}_{2}$ 発生量を Warburg 検圧 計を以て測定した。

\section{実 験 成 績}

\section{1) $\mathrm{H}_{2} \mathrm{O}_{2}$ 濃度と peroxidase 活性測定值と の関係}

peroxidase 源として標品 peroxidase $50 \gamma$ を用い， 1 容器当り $\mathrm{H}_{2} \mathrm{O}_{2}$ 1. 5. 10. 20. $30 \mu$ mol. を入れて, peroxidase 活性を測定した 所, Fig. 2 の如く, $\mathrm{H}_{2} \mathrm{O}_{2}$ の濃度の増加と 共に測定活性值は上昇するが，20 $\mu \mathrm{mol}$. でほ ぼ最高に達し，30 $\mu \mathrm{mol}$. ではやや低值とな る。

\section{2) I-tyrosine 添加の影響}

Fig. 2. Relationship between Peroxidase activity and Concentration of $\mathrm{H}_{2} \mathrm{O}_{2}$

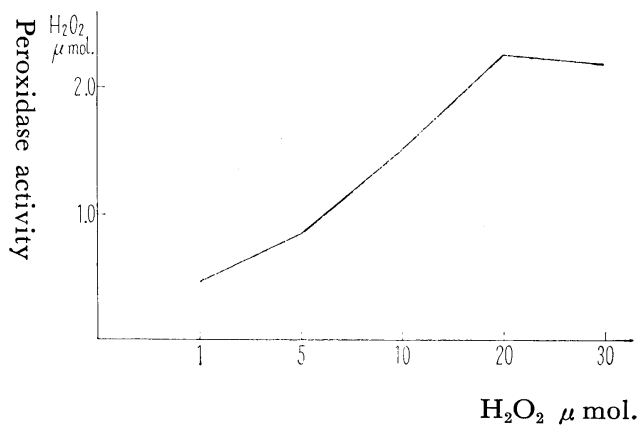

第38巻 第11号 
peroxidase 源として, 標品 peroxidase $50 \gamma$ を用い, $\mathrm{H}_{2} \mathrm{O}_{2}$ の濃度を $20 \mu \mathrm{mol}$. とし，他は実験方法の 項に記載したと同一条件にて，基質に1容器当り 1-tyrosine $30 \mu \mathrm{mol}$. を添加した場合と, 添加しない場合 との peroxidase 活性値を測定した処，Table 1 の如く両者の間に殆んど差異を認めなかつた.

Table 1. Peroxidase activity with or without adding l-tyrosine

\begin{tabular}{c|c|c|c|c|c}
\hline Time (min.) & 2 & 4 & 6 & 8 & 10 \\
\hline \hline Standard peroxidase (l-tyrosine (+)) & 2.3 & 2.4 & 2.9 & 3.1 & 3.3 \\
Standard peroxidase (l-tyrosine (-)) & 2.1 & 2.4 & 2.7 & 2.9 & 3.2 \\
\hline
\end{tabular}

\section{3) Peroxidase の各種濃度とその活性測定} 値

$\mathrm{H}_{2} \mathrm{O}_{2}$ 濃度を 1 容器当り $20 \mu \mathrm{mol}$. とし, 標品 peroxidase の濃度を, 1 容器当り 1 , $5,10,50,100,1000 \gamma$ として, peroxidase 活性值を測定した処, Fig. 3 の如くの peroxidase 濃度が増加するにつれ，その活 性值の上昇するのを認めた。

4) モルモット甲状腺 homogenate の酸素 消費量 $\left(Q_{o_{2}}\right)$ の測定
Fig. 3. Peroxidase activities at various Concentrations of peroxidase

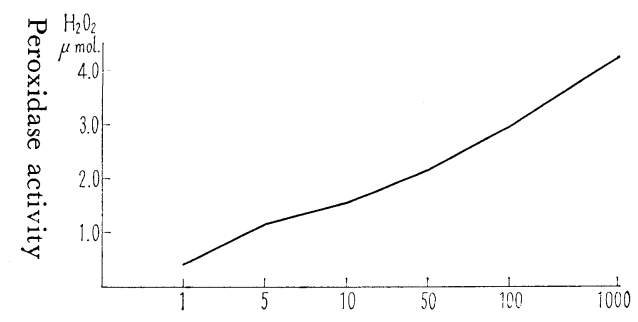

Concentration of standard peroxidase $(\gamma)$

Table 2. Oxygenconsumption of Thyroid homogenate of male guinea pig

\begin{tabular}{cr|r|r|r|r|r}
\hline & No. & I & II & III & IV & mean \\
\hline \hline Time (min.) & 2.5 & 2.2 & 2.0 & 2.8 & 2.4 \\
10 & 5.0 & 4.5 & 4.6 & 5.1 & 4.8 \\
20 & 9.4 & 9.7 & 9.2 & 10.2 & 9.6 \\
40 & 14.8 & 14.0 & 14.1 & 14.8 & 14.4 \\
60 & & & \\
\hline
\end{tabular}

homogenate の酸素消費を，10分，20分，40分，60分と 経時的に測定した結果，Table 2 亿示す如く酸 素消費量 $\mathrm{Qo}_{2}(\mu \mathrm{l} . / \mathrm{mg}$./hrs.) は，14.4 $\mu \mathrm{l}$. の微量であつた。 なお標品 peroxidase では, 酸素消費量は零で あつた.

\section{5 ) 反応時間と peroxidase 活性測定值}

1 容器当り $\mathrm{H}_{2} \mathrm{O}_{2} 20 \mu \mathrm{mol}$. 亿て, 標品 peroxidase の場合は $50 \gamma$, homogenate では $50 \mathrm{mg}$. を使用し て，その peroxidase 活性值を， 2 分，4 分，6 分， 8 分，10分の 5 回にわたり測定した処，共に Fig. 4 の如き值を得た，標品 peroxidase を用いた場合でも, 甲状腺 homogenate を用いた場合でも, 反応時間 の経過と共に, peroxidase 活性の上昇を見た. 又, 甲状腺 homogenate を用いた場合に比へて, 標品 peroxidase を用いた場合の方が活性値の高い事を認めた。

6) Ettori 法による peroxidase 活性の測定值

標品 peroxidase の濃度を，1，10，50 として，それぞれの $\mathrm{CO}_{2}$ 発生量を，Warburg 検圧計を用いて 測定した処, Fig. 5 の如く, peroxipase の莀度の増加と共に, $\mathrm{Co}_{2}$ 発生量の増加するの在認めた. 併し本 法では，100 以上は測定出来なかつた. 
Fig. 4. Peroxidase activities at Response Time

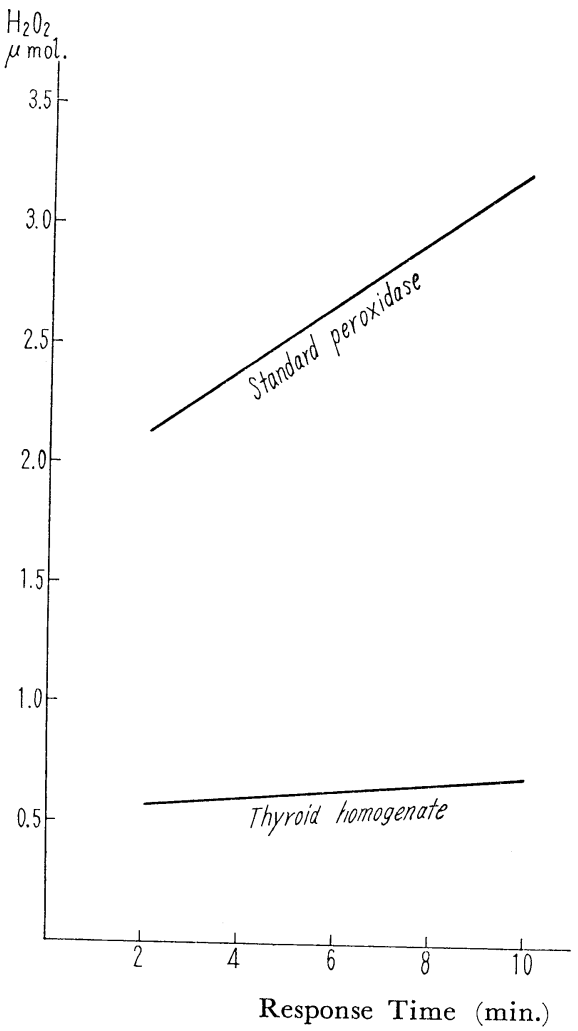

Fig. 5. Peroxidase activity measured by Ettori's method

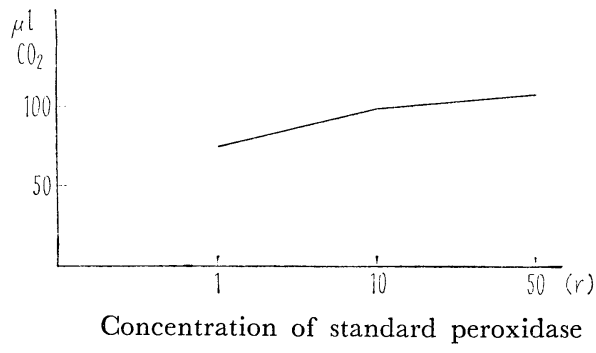

考

peroxidase 活性測定法には， purpurogallin 法, guajacol 法, Ettori 検圧法, Randall 法等がある が，著者は Randall 法を改良し，基質に沃度化合 物を添加し, peroxidase による $\mathrm{H}_{2} \mathrm{O}_{2}$ の消失率を Warburg 検圧計を用いて測定し，その沃度酸化利 用酸素量を以て, peroxidase の活性を測定すると 同時に，沃度アミノ酸の推移を観祭し得る測定法を 案出した。

本測定法の原理として, peroxidase による $\mathrm{H}_{2} \mathrm{O}_{2}$ の分解は, $\mathrm{H}_{2} \mathrm{O}_{2} \stackrel{\text { peroxidase }}{\longrightarrow} \mathrm{H}_{2} \mathrm{O}+\mathrm{O}$ で, この発 生機の酸素は, 直ちに沃度酸化に利用されるか ら, $2 \mathrm{I}^{-}+\mathrm{O}^{--}+2 \mathrm{H}^{+} \rightarrow 2$ “active $\mathrm{I}^{\prime}+\mathrm{H}_{2} \mathrm{O}$, 又は,

$\mathrm{H}_{2} \mathrm{O}_{2}+2 \mathrm{I}^{-}+2 \mathrm{H}^{+} \stackrel{\text { peroxidase }}{\longrightarrow} 2$ "active $\mathrm{I}+2 \mathrm{H}_{2} \mathrm{O}$ と

なり,ての $\mathrm{O}^{--}$は直ちに $2 \mathrm{H}^{+}$と結合して $\mathrm{H}_{2} \mathrm{O}$ となり, $\mathrm{O}_{2}$ ガスとはならないので, manometer には現れない これに反して catalase が $\mathrm{H}_{2} \mathrm{O}_{2}$ に作用すると， $2 \mathrm{H}_{2} \mathrm{O}_{2} \stackrel{\text { catalase }}{\longrightarrow} 2 \mathrm{H}_{2} \mathrm{O}+\mathrm{O}_{2}$ となり， $\mathrm{O}_{2}$ ガスの形で酸素が 発生するので，てれが manometer に現れる。故に添加した $\mathrm{H}_{2} \mathrm{O}_{2}$ に, peroxidase を一定時間作用させ た後に, 残つた $\mathrm{H}_{2} \mathrm{O}_{2}$ を catalase によつて分解させ, 発生した酸素量を, 同時に別の容器で同量の $\mathrm{H}_{2} \mathrm{O}_{2}$ を, catalase のみで分解させた時に発生する総酸素量から差引くと，沃度酸化に利用された発生機酸素の量 が得られる。乙れを peroxidase の活性值とするのである。本法に於て，先ず $\mathrm{H}_{2} \mathrm{O}_{2}$ 濃度を変化させた場合 の， peroxidase の活性值を測定した処，Fig. 2 の如く， $\mathrm{H}_{2} \mathrm{O}_{2}$ 濃度が増加すると共に, peroxidase 活性測

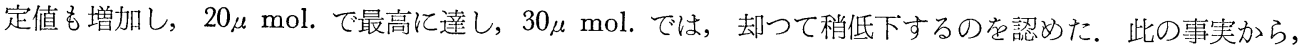
本法を行う場合には, 1 容器当り $\mathrm{H}_{2} \mathrm{O}_{2} 20 \mu \mathrm{mol}$. を入れるのが適当と考えられる. 従つて, 以下の実験に は, すべて $\mathrm{H}_{2} \mathrm{O}_{2}$ の濃度を 1 容器当り $20 \mu \mathrm{mol}$. とした.

次に，著者の考案した方法では，沃度代謝をも同時に検討する為に，容器中に l-tyrosine を混入するの であるが，ての添加した l-tyrosine が， peroxidase 活性值に影響を及ぼすか否かを検討した処，Table 1 の如く, l-tyrosine を添加した場合の peroxidase 活性測定值と, 添加しない場合のそれとの間に, 有意の 差を認めなかつた. 従つて, l-tyrosine 1 容器当り $30 \mu$ mol. を入れても, peroxidase 活性值の測定が可 能である事を知つた.

更に, peroxidase の濃度と, その活性測定值との関係を検討する為に, $\mathrm{H}_{2} \mathrm{O}_{2}$ 濃度を 1 容器当り $20 \mu \mathrm{mol}$. として，標品 peroxidase の濃度をいろいろ変えてその活性值を.測定した処，Fig. 3 に見られる如く， 
peroxidase 量の増加と共に, その活性測定値も増加する. 此事実から, peroxidase 量とその活性測定值と の間に, 一定の比例関係の成立し得るのを確め得た。従つて, 此測定法は, peroxidase の活性值測定法と して用い得る事を確認した.

以上は，標品を用いた実験であつたが，甲状腺 homogenate を用いた場合，甲状腺組織が $\mathrm{O}_{2}$ を消費す る為に，測定值が変動する事が考光られるが，Table 2 で明らかにした様に， $\mathrm{Qo}_{2}$ は $14.4 \mu l$. と云う微量で あつた事から, 本法に於て, 標品 peroxidase に代えて甲状腺 homogenate を用いた場合でも, 標品 peroxidase を用いた場合と同様, $\mathrm{Qo}_{2}$ は無視し得ると考えられる.

以上の種々の基礎的実験の結果より, 1 容器当り $\mathrm{H}_{2} \mathrm{O}_{2} 20 \mu$ mol. 標品 peroxidase $50 \%$. homogenate は $50 \mathrm{mg}$ を用いる事とし， 2 分乃至10分間反応せしめた処, その peroxidase 活性值は, Fig. 4 の如く, 両者 共時間と共に直線的に上昇するのを確めた。併し，標品 peroxidase を用いた場合の方が，その絶刘量が多 く，又，比較的精製されたものである為，甲状腺 homogenate 亿比し活性值が高いのを認めた。

更に，Ettori 法により，標品 peroxidase の活性を測定した処，Fig. 5 の如き成績を得た。即ち， peroxidase の各種濃度とその活性値を測定すると, peroxidase 量が増加するにつれ, その活性測定值の上 昇するのを認めた。併し, Ettori 法に於ては， $\mathrm{H}_{2} \mathrm{O}_{2} 0.01 \mathrm{M} 1.5 \mathrm{ml}$. を使用しているので, $\mathrm{CO}_{2}$ 発生量は, 計算上 $112 \mu l$ が限界となる。従つて peroxidase 量が100 以上の場合は，Fig. 5 の結果から見て明らかな 如く測定不能であつた，更に，比の Ettori 法は，基質に沃度化合物を添加していないから，沃度生成物の 推移を見る事は不可能である.

以上の基礎的な検討の結果から，著者の考案せる方法は， gasmetry 法としての peroxidase 活性測定法 として利用し得るものであり，且つ同じく gasmetry 法として従来賞用されて来た Ettori 法に比べて，そ の測定範囲が広いと云う長所がある，又，原法である Randall 法では，基質に沃度化合物を含まないから， 沃度代謝を追求する事は出来ないが，著者の考案した本法では，基質に沃度化合物を添加してあるから，反 応後の沃度生成物をも同時に検索し得ると云う利点がある。

\section{結論}

Randall の peroxidase 測定法を改良し，その基質に KI，及び l-tyrosine を添加し， $\mathrm{H}_{2} \mathrm{O}_{2}$ の消失率を Warburg 検圧計を用いて測定すると同時に，その際の沃度ア之ノ酸の推移を究明し得る peroxidase 活性 測定法を案出し，その基礎的実験条件を検討した.

1) 此測定法では, 1 容器当り使用する $\mathrm{H}_{2} \mathrm{O}_{2}$ 量は, $20 \mu \mathrm{mol}$. が最適である.

2) 1-tyrosine 渿加による peroxidase 活性值への影響は認められなかつた，従つて基質に l-tyrosine を 添加して差支えない事を知つた。

3 ）標品 peroxidase の濃度と，本法で測定したその活性値とは，略々正比例する事から，本法は peroxidase 活性の測定に用い得る事を確認した.

4) モルモット甲状腺 homogenrte そのものの酸素消費量は, 極めて微量である事から, 甲状腺 homogenate を反応系に加えた場合でも，活性值への影響は無視し得る。

$5)$ 標品 peroxidase, 又は甲状腺 homogenate と $\mathrm{H}_{2} \mathrm{O}_{2}$ との反応時間と, 本法で測定した peroxidase 活性值とは，正比例する。

6) Ettori 法は，本法に比べて測定範囲か限られている.

7 ) 本法では, 基質として沃度化合物を添加しているから, 反応後の沃度アミノ酸の推移を, peroxidase 活性の変動と同時に究明する事が出来る筈である. 


\section{第二章「甲状腺 peroxidase，及び沃度アミノ酸生成に及ぼす 甲状腺剌戟ホルモンの影響」}

\section{まえがき}

甲状腺の沃度代謝は，体外より掑取されて無機沃度が腸管より吸収され，血液中に移行し，更に甲状腺に とり込まれるが，ての沃度イオンは，甲状腺滤胞上皮の細胞膜を通過して細胞内に侵入すると直ちに， peroxidase により酸化されて $\mathrm{I}_{2}$ となる．乙の酸化された沃度分子は甲状腺蛋白分子の tyrosine 基に結合 し，出来た diiodotyrosine の 2 分子は，更に縮合して thyroxine となる. thyroxine の殆んぞ総ては globulin 分子に結合し， thyroglobulin として肺状腺濾胞中に眝蔵される．以上の様な甲状腺の沃度代謝 は，TSH によつて促進されるが，甲状腺組織内で沃度の酸化に関与する peroxidase の活性が，TSH に よつて賦活される事は，1946年，De Robertis $\left.{ }^{9}\right) \&$ Grassoにより組織化学的に検討が行われて来た.

TSH が甲状腺の沃度拱取，及び沃度有機化に及ぼす影響については，Leblond, ${ }^{18)}$ Morton, ${ }^{19}$ 等の如く種 々の報告があるが，従来の研究を通覧すると，TSH が選択的に peroxidase 活性を高めるとする説と， TSH が甲状腺の機能を全般的に元進させ, その結果として沃度代謝の充進を見ると云う説と, TSH が甲 状腺の沃度代謝を促進する為に，二次的に沃度有機化を促進させると云う説の 3 つ大別出来るが，何れも 推定の域を脱せず，未だはつきりとした定説が見られない.

そてで私は, peroxidase 及び甲状腺に於ける沃度代謝の機構に TSH が如何に作用するかを, 前章に記 述した測定法を用い, 即ち manometry と paparchromatography を併用して研究し, 些かの新知見を得 たのでここに報告する。

\section{実験材料並びに方法}

\section{I. 実験材料}

前章に記載したと同じ.

但し, TSH としては, Pretiron (Schering Co.) を生理的食塩水にて溶解し, TSH 溶液は氷室に保存 し, 少くとも 5 日以内に使用した。此, TSH を 1 容器当り $10^{-1}-10^{-2}-10^{-3}-10^{-4} \mathrm{~J}$. S.U. となる様に基質 に添加した。 なお, $\mathrm{H}_{2} \mathrm{O}_{2}$ は 1 容器当り $20 \mu \mathrm{mol}$. を使用し, 基質としての KI を 1 容器当り $40 \mu \mathrm{mol}$. と し, てれに l-tyrosine を 1 容器当り $30 \mu \mathrm{mol}$. 添加した.

反応終了後の生成物の検出には, 東洋滤紙No.51を以て, paperchromatography を行つたが，展開液と して n-butanol-acetic acid-water (75:10:15) を用いた。

\section{II. 実験方法}

実験方法は以下の如く行う。

\section{1) 実験装置}

前章と同し

\section{2) 実験操作}

Gasmetry の操作は, 前章に記載通りである。

反応終了後の溶液の paperchromatagraphy は次の様に行つた。即ち, Warburg 検圧計を用いて, peroxidase 活性值を測定した後の，主室中の溶液の水分を出来るだけ蒸発し，その約 5 倍量の n-butanol, アンモニア $(50: 1)$ 溶液を加え振䔽抽出の後, その抽出液を濃縮して, 東洋濾紙No. 51 の一端に塗抹した.

展開液には, n-butanol-acetic acid-water $(75: 10: 15)$ を用い, 一次元上昇法で展開した。 約 $25 \mathrm{~cm}$ 展 開させた後, 濾紙は室温で風乾した。呈色には，0.5\% ninhydrin 溶液を用い，風乾した展開滤紙に噴霧 し，90 $\mathrm{C} 10$ 分間発色を行つた。標準物質として， monoiodotyrosine, diiodotyrosine, 353'l-triiodothyronine, 
l-thyroxine，を使用し，主室内容液の抽出液と同時に展開し，同様の操作で発色し，それ等の Rf. より， 未知の spot の沃度アミノ酸の種類を判定した.

\section{実 験 成 績}

\section{A. peroxidase 活性值}

\section{a. 標品 peroxidase を用いた実験}

標品 peroxidase 活性に及ぼす TSH の影響を，逐時的に検討した結果は，Fig. 6 亿示す如くである。

Fig. 6. Peroxidase activity with adding TSH (standard peroxidase)

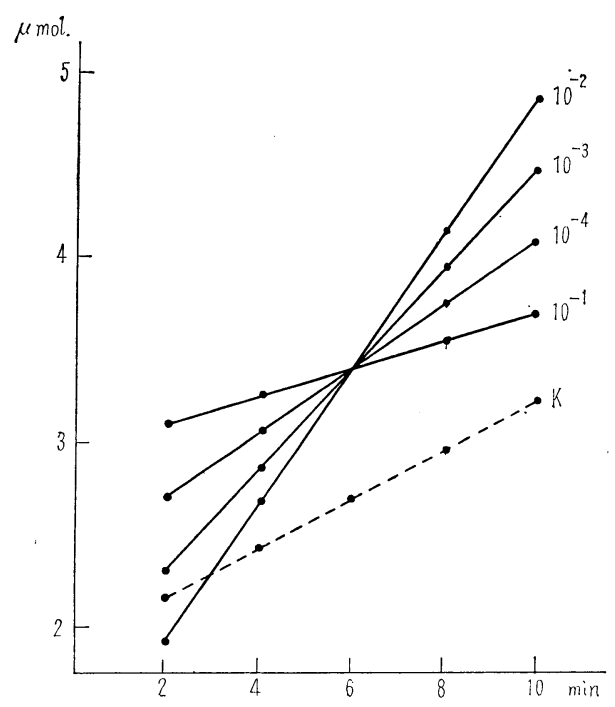

Fig. 7. Relationship between TSH Concentration and Peroxidase activity studied at different time.

(Standard peroxidase)

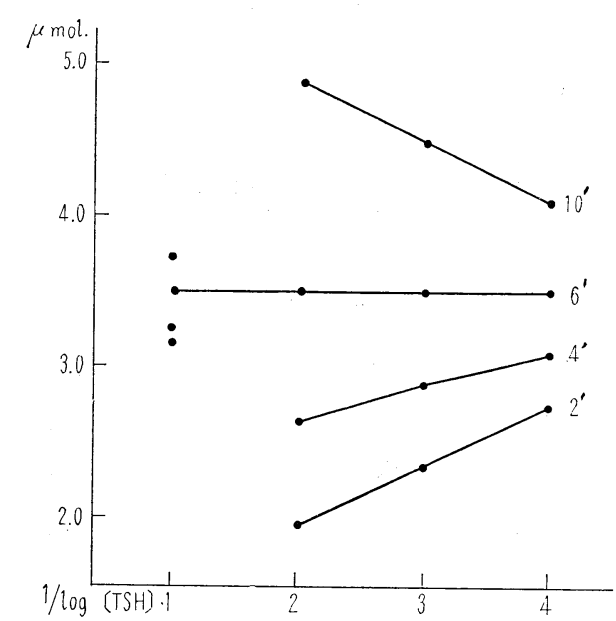

即ち, $10^{-1}, 10^{-2}, 10^{-3}$, 及び $10^{-4}$ J.S.U. の濃度の TSH を反応系に加え, 2 分, 4 分, 6 分, 8 分, 10分の順に，各々 catalase を添加する事により peroxidase の反応を停止せしめ， 2 分，4分，6 分，8 分，10分間反応せしめた時の，それぞれの peroxidase 活性值を測定したが，各濃度の TSH を加えた場合 の peroxidase 活性値は，夫々時間的経過と共に増加するが，その增加率はTSH の各濃度によつて異つて いる．而し，6 分間反応せしめた場合は，その活性值は略々等しく，10分間反応せしめた場合は，その活性 值の大さの順は， $10^{-2}, 10^{-3}, 10^{-4}, 10^{-1} \mathrm{~J} . S . U$. であり，対照とした TSH を加えない場合に比して，何れ も活性值が大であつた。更にての成績を反応時間別に，TSH 濃度と peroxidase 活性值との関係を図示す ると, Fig. 7. の如くである. 2 分，4 分，6 分では，両者の関係は直線的でないが，10分間反応せしめた 場合は，TSH 濃度と peroxidase 活性測定值とが，ほぼ完全な直線関係を示している。此，実験結果から 見て， peroxidase 活性は，10分間反応せしめた後に測定するのが，最適である事を示している.

次に, 以上の両者の相互関係を推計学的に検討する為に，標品 peroxidase を用い，TSH を添加し10分 間反応せしめた実験を詳細に行つたが，その場合の peroxidase 活性測定值は，Table 3 の通りであつた。 てれをグラフに示すと，Fig. 8 の如くである。乙の第 3 表の実験值より，TSH の各濃度を作用せしめた場 合の，夫々の peroxidase 活性測定值を，推計学的に検討した。併し，TSH $10^{-1}$ J.S.U. を添加した場合の

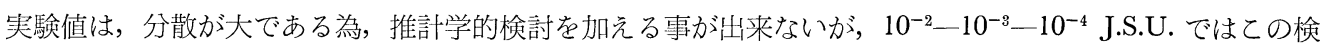
討を行い得た. TSH の各種濃度添加時の peroxidase 活性值間の有意差の検討を行つた処，危険率 $\mathrm{p}=5$ \%に於て有意差を認めた. 更に此， 3 種の濃度の TSH を添加した場合の，用量反応曲線の直線性の検定

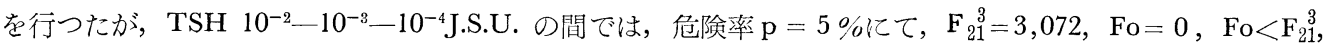


Table 3. Peroxidase activity with adding TSH (standard peroxidose)

\begin{tabular}{c|c|c|c|c|c|c|c|c|c|c|c}
\hline & I & II & III & IV & V & VI & VII & VII & total & mean \\
\hline \hline $\mathrm{K}$ & 0.31 & 0.43 & 0.37 & 0.69 & 0.46 & 0.94 & 0.87 & 0.31 & 4.38 & $\begin{array}{c}0.548 \\
\pm 0.064\end{array}$ \\
\hline $10^{-1}$ & 0.50 & 1.33 & 2.31 & 0.37 & 0.62 & 0.40 & 2.50 & 2.54 & 10.57 & $\begin{array}{c}1.32 \\
\pm 1.286\end{array}$ \\
\hline $10^{-2}$ & 2.54 & 2.77 & 2.53 & 2.52 & 2.76 & 2.52 & 2.93 & 2.47 & 21.04 & $\begin{array}{c}2.63 \\
\pm 0.027\end{array}$ \\
\hline $10^{-3}$ & 1.72 & 1.58 & 1.76 & 1.59 & 1.91 & 1.80 & 1.16 & 2.19 & 13.71 & $\begin{array}{c}1.71 \\
\pm 0.088\end{array}$ \\
\hline $10^{-4}$ & 0.76 & 0.62 & 0.85 & 0.56 & 1.11 & 0.72 & 0.97 & 0.74 & 6.33 & $\begin{array}{c}0.79 \\
\pm 0.031\end{array}$ \\
\hline
\end{tabular}

Fig. 8. Peroxidase activity with adding TSH (standard peroxidase)

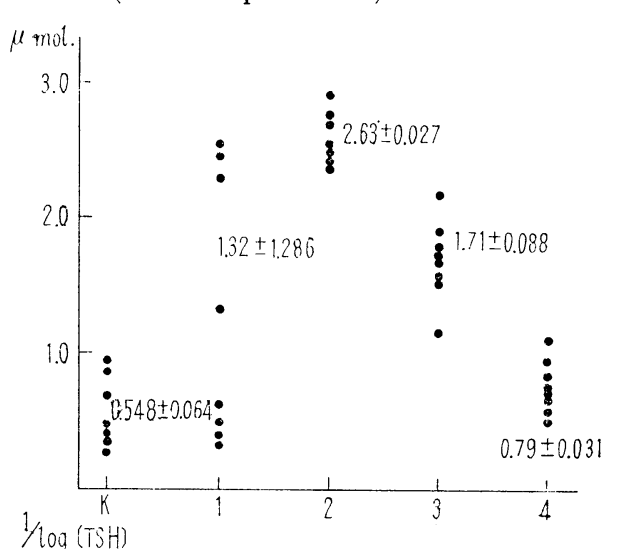

Fig. 10. Peroxidase activity with adding TSH (homogenate)

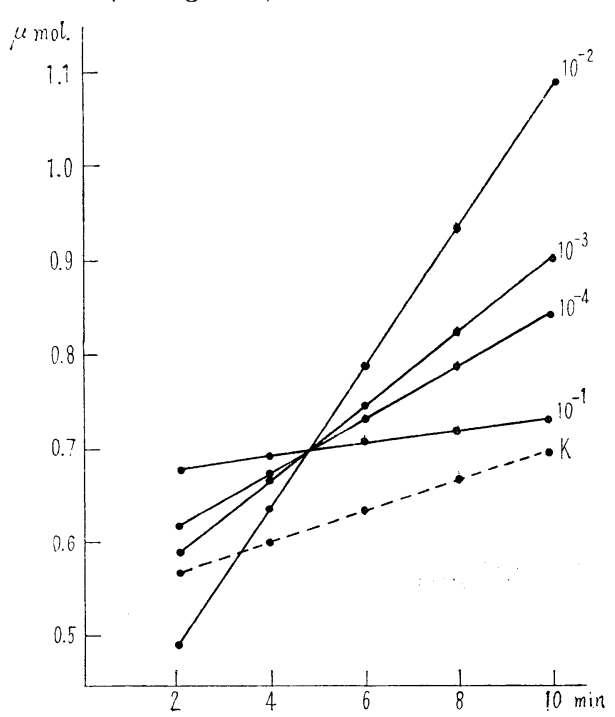

Fig. 9. Dose Response Curve (standard peroxidase)

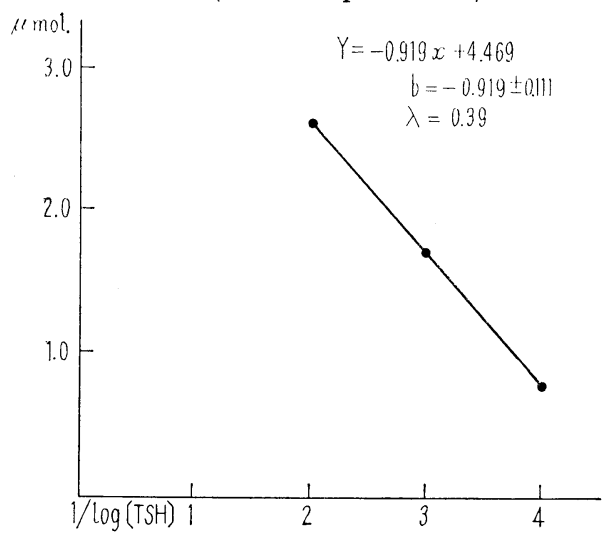

Fig. 11 Relationship between TSH Concentration and Peroxidase activity studied at different time

(homogenate)

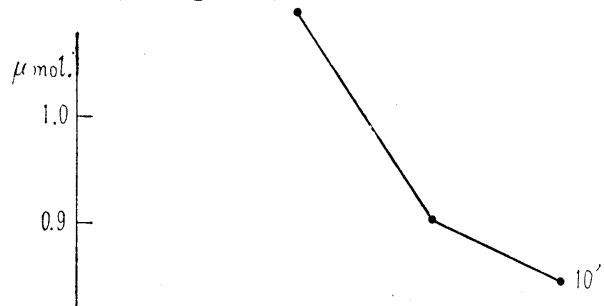

0.8

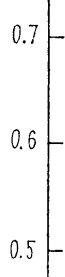

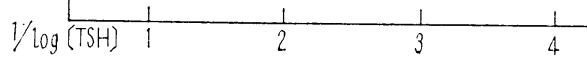


であつた，従つてその用䁷反応曲線の直線性が成立し, 回帰係数 $\mathrm{b}=0.919$ となるから, 最良近似曲線は, Fig. 9 の如く, $\mathrm{Y}=-0.919 \mathrm{x}+4,469, \lambda=0.39$ となる。此の際の回帰係数 $\mathrm{b}$ 亿対する信頼限界を，危険率 $\mathrm{p}=5 \%$ で検討した処， $\mathrm{b}$ が有意である事が認められた。即ち, 標品 peroxidase 用いた実験では， $10^{-2}$, $10^{-3}$ ，及び $10^{-4} \mathrm{~J} . S . U$. の範囲内で，TSH 濃度と，TSH を添加した場合の peroxidase 活性值との間に， 推計学上有意の関係が認められた。

\section{b. モルモット甲状腺 homogenate を用いた実験}

peroxidase 源として，モルモット甲状腺 homogenate を用い，TSH がその活性值に及ぼす影響を，時

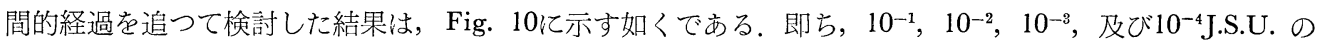
濃度の TSH を反応系に加光， 2 分，4 分，6 分， 8 分，10分の順に，各々 catalase を添加する事により peroxidase の反応を停止せしめ, 2 分， 4 分， 6 分， 8 分，10分間反応せしめた場合の, peroxidase 活性 を測定したが，TSH の各濃度を加えた場合の peroxidase 活性值は, 夫々時間的経過と共に增加するが，そ の増加率は TSH の各濃度によつて異つている. 而し, 約 5 分間反応せしめた場合は, その活性值は略々 等しく, 10分間反応せしめた場合は, その活性值の大さの順は, $10^{-2}, 10^{-3}, 10^{-4}, 10^{-1} \mathrm{~J}$. S.U. であり, 対照 としたTSH を加えない場合に比して，何れも活性值が大であつた．更に，ての成績を反応時間別に，TSH 濃度と peroxidase 活性値との関係を図示すると, Fig. 11 の如くである. 4分間反応せしめた場合, やや直 線に近づいている．10分間反応せしめた場合の peroxidase 活性測定値は，標品 peroxidase を用いた場合 と異り，直線とはならなかつた．併し，標品 peroxidase を用いた場合と比較する為に，10分間反応せしめ た場合の実験值 (Table 4 を推計学的に検討した. その実験值をグラフで表わすとFig.12の如くである．と

Table 4. Peroxidase activity with adding TSH (homogenate)

\begin{tabular}{c|c|c|c|c|c|c|c}
\hline & I & II & III & IV & V & total & mean \\
\hline $\mathrm{K}$ & 0.21 & 0.85 & 0.92 & 0.51 & 0.99 & 3.48 & $\begin{array}{c}0.696 \\
\pm 0.651\end{array}$ \\
\hline $10^{-1}$ & 0.11 & 0.39 & 0.89 & 0.95 & 1.33 & 3.67 & $\begin{array}{c}0.734 \\
\pm 0.965\end{array}$ \\
\hline $10^{-2}$ & 0.81 & 1.45 & 1.52 & 0.71 & 1.05 & 5.54 & $\begin{array}{c}1.108 \\
\pm 0.752\end{array}$ \\
\hline $10^{-3}$ & 0.58 & 0.77 & 1.12 & 1.25 & 0.85 & 4.57 & $\begin{array}{c}0.914 \\
\pm 0.540\end{array}$ \\
\hline $10^{-4}$ & 0.70 & 0.95 & 1.20 & 0.65 & 0.78 & 4.28 & $\begin{array}{c}0.856 \\
\pm 0.446\end{array}$ \\
\hline
\end{tabular}

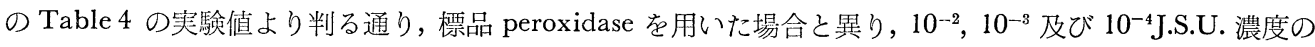
TSH 添加時の， peroxidase 活性測定值の分散が大である。TSH を添加しない場合，即ち，対照と各種 TSH 濃度を添加した場合との peroxidase 活性測定值間には，有意差を認めず，又，TSH の各濃度によ る peroxidase 活性測定值間にも，危険率 $\mathrm{p}=5 \%$ で，何れに於ても有意差は認められなかつた，更に，此 3 種の濃度の TSH を添加した場合の, 用量反応曲線の直線性の検定を行つたが，TSH $10^{-2}, 10^{-3}$, 及 び $10^{-4}$ J.S.U. の間では，危険率 $\mathrm{p}=5 \%, \mathrm{~F}_{12}^{3}=3.49, \mathrm{Fo}_{\mathrm{O}}=0.069$, となり $\mathrm{Fo}_{0}<\mathrm{F}_{12}^{3}$ であつた。 従つて，その 用量反応曲線の直線性が成立し, 回帰係数 $\mathrm{b}=-0.127$ となるから, 最良近似曲線は, Fig. 13 の如く, $\mathrm{Y}=-0.127 \mathrm{x}+1.34, \lambda=7.99$ となる，此の際の，回帰係数 $\mathrm{b}$ 亿対する信頼限界を，危険率 $\mathrm{p}=5 \%$ で検 討した処， $\mathrm{b}$ が有意であるとは認められなかつた，即ち，推計学上， peroxidase 源として，モルモット甲 状腺 homogenate を用いた場合では，TSH 各種濃度と peroxidase 活性測定值との間に，有意の関係が認 められなかつた。 
Fig. 12. Peroxidase activity with adding TSH (homogenate)

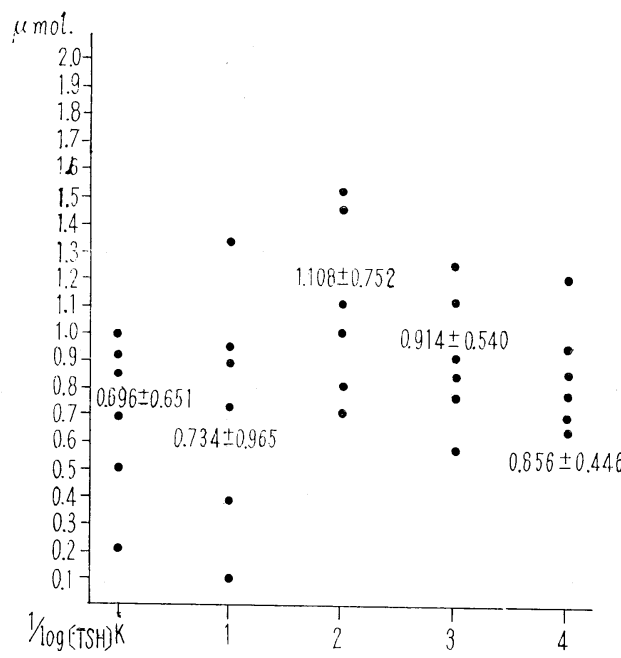

B) 反応溶液の paperchromatography

a) 標品 peroxidase を用いた実験

標品 peroxidase を用いた実験の，反応溶液の paperchromatography では, monoiodotyrosine, diiodotyrosine の spot が，共にかなり明暸に表わ れ，しかもその生成量は，TSH 濃度により異つて いる。即ち，TSH $10^{-2}, 10^{-3}$ J.S.U. で spot はか なり濃く，てれを densitometer にかけた処，Fig. 14の如く, TSH $10^{-2}$ J.S.U. で monoiodotyrosine, diiodotyrosine の生成量が最も多く, TSH10 $10^{-3}$, $10^{-4}, 10^{-1}$ J.S.U. 対照の順に，その生成量が減少し ている. 又, 添加した tyrosine の量は, monoiodotyrosine, diiodotyrosine，の量に反比例して減少 している.

b）モルモット甲状腺 homogenate を用いた実験 雄モルモット甲状腺 homogenate を用いた場合 の，反応溶液の paperchromotography では， monoiodotyrosine, diiodotyrosine, 共に淡い spot
Fig. 13. Dose Response Curve (homogenate)

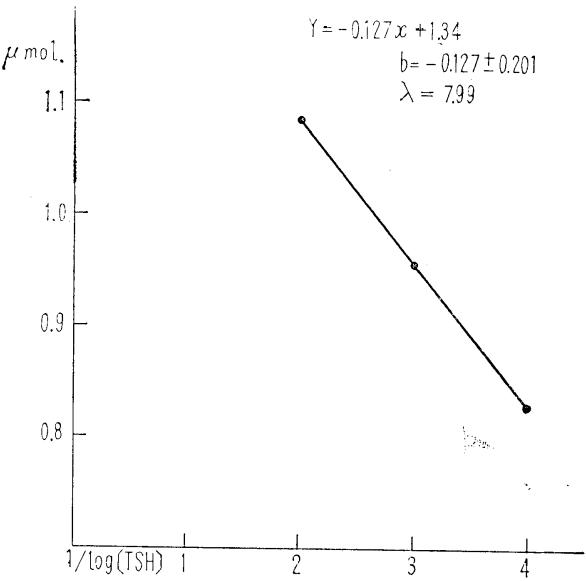

Fig. 14. Densitogram of fractions separated by Paperchromatography of test solution.
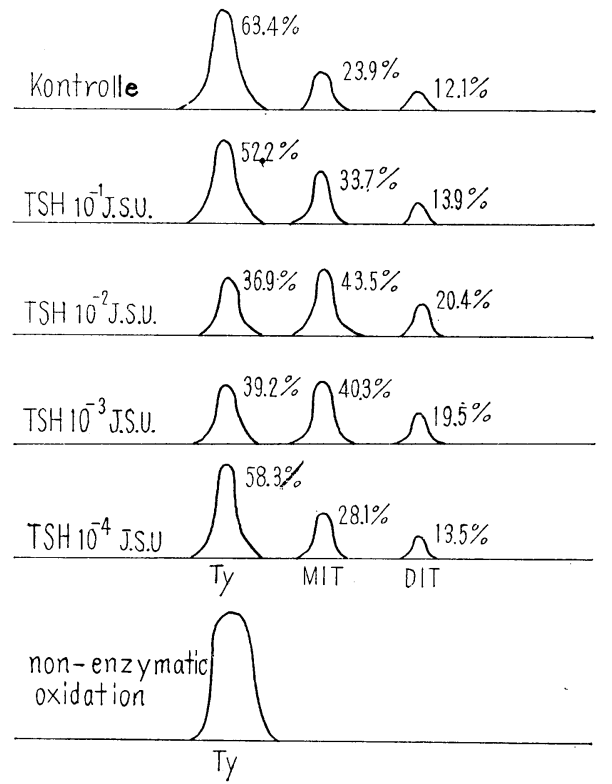

として表われるが，その spot の濃度と添加した TSH の濃度との相関関係は，明らかでなかつた。

C) Peroxidase を添加しなかつた実験.

尚，Fig. 14 の最下段は，酵素源である標品 peroxidase，及び homogenate を反応系に添加せず，他は 全く同様に操作した場合の反応溶液の， paperchromatography の densitometer の所見であるが，monoiodotyrosine, diiodotyrosine は全く生成されていない事を示している.

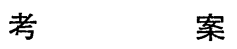

甲状腺に於ける TSH の作用点については，種々論議されている所である。即ち，抗甲状腺剂，及び $\mathrm{I}^{131}$ 第38巻 第11号 
の導入によつて，TSH は甲状腺の機能の総ての面に作用する事が明らかにされた，即ち，沃度摂取，甲状 腺ホルモン合成, thyroglobulin 貯蔵, 甲状腺ホルモン分泌等が TSH により促進されるのである. しか し, TSH の作用が，甲状腺の何れの機能に最も早く現われるか，又，甲状腺機能を全面的に六進するもの であるかどうかは，今日尚，諭議されている処である.

その内, TSH が選択的に peroxidase 活性を高めるとする説では, 組織化学的研究により, 1946年, De Robertis, ${ }^{9)}$ \& Grasso は, ラットに5 単位の Thyrotropin を注射し, 甲状腺細胞とコロイドの双方に於て, 対照と比較して明らかに peroxidase 反応の陽性化を認めた事から, TSH が peroxidase の活性を賦活す ると報告した，次に Keating ${ }^{20)}$ (1945). Rawson ${ }^{21)}$ (1949), Olin, Lamberg ${ }^{22}$ (1953) 等は，甲状腺内の有機 沃度が減れば，当然 $\mathrm{I}^{191}$ 摄取が方進する訳であるが，TSH の作用が有機沃度減少を招いて，その結果とし て $\mathrm{I}^{131}$ 椇取を促進すると述べている. 次いで Leblond \& Süe ${ }^{18)}$ (1941), Morton ${ }^{19)}$ (1941), Stanley \& Astwood $^{23)}$ (1949) 等は, TSH そより総ての沃度有機化の過程, 特に diiodotyrosine から thyroxine の過程が促進されると云つている。

扱て, 著者の実験によつて, peroxidase 源として標品 peroxidase, 又はモルモット甲状腺 homogenate を用い TSH を添加すると, TSH を添加しない場合に比して peroxidase 活性が上昇し, 両者共 TSH $10^{-2}-10^{-3}-10^{-4}$ J.S.U. の範囲で, TSH 濃度と peroxidase 活性值との間に, 直線関係を認めた事は, TSH によつて peroxidase が賦活されたものと云い得る。此事実から，TSH が直接的に peroxidase 活性 を賦活する事が明かとなつた。

而も， peroxidase に対する TSH の賦活作用が，標品 peroxidase を用いた場合でも，甲状腺 homogenate を用いた場合と同様に，寧ろより著明に証明された事，即ち，植物性 peroxidase たる標品 peroxidase も， 動物性 peroxidase たる甲状腺 homogenate も，共に同様に賦活される事実から，沃度酸化関与する peroxidase そは特異性はないものと考光られる，peroxidase の特異性については，従来より諸説があり一 致していないが, 以前は特異性があるとの説が有力であつた。鈴木 ${ }^{24}$ も著者の此報告に対し, 蕉の peroxidase を用いた実験で，沃度酸化が行われなかつた事から，植物性 peroxidase と動物性 peroxidase との間に相 違する点のある事を述べているが，Klebanoff (1959.1961. 1962) は, 植物性 peroxidase たる horse radish peroxidase も，動物性 peroxidase たる lacto-peroxidase（牛乳），及び myelo-peroxidase（骨髄）も，沃 度の酸化に於ては同じ態度である事より，peroxidase には特異性がないと述べている。

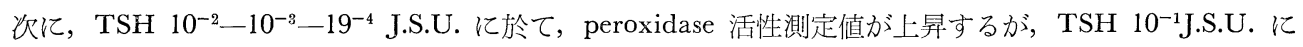
於て peroxidase 活性測定値は, 却つて低下していると云う結果を得たが, 此の TSH の浱度差による作用 上の相違は, 所謂 2 相性作用 (少量刺㦸, 大量抑制) と考光られる。即ち, 高濃度 TSH の場合, TSH が peroxidase 活性を賦活し, 多量の沃度分子を生じ, 此の結果, TSH 自身が沃度化され急速に TSH の活性 を失い，従つて peroxidase 一の賦活作用が低下する。 それに反し，低濃度である TSH $10^{-2}-10^{-3}-10^{-4}$ J.S.U. では, TSH 自身の沃度化される事が少く, 従つて peroxidase を賦活する為に, 反応時間に比例し て peroxidase 活性值が増加し, その増加率は此濃度範囲内の TSH 濃度に比例するものと考元られる. 以上鬼に角, peroxidase を賦活する TSH 濃度には, 至適濃度閾値の存在する事が予想される。

次に peroxidase 源として甲状腺 homogenate を用いた場合より, 標品 peroxidase を用いた場合の方 が，TSH 添加による peroxidase 活性値の増加が著明である事の理由として, 先ず考孚られる事は, 標品 の方が peroxidase 含有量が多い事, 標品は純化されている為に, deiodinase 等の沃度代謝汗渉するもの が混在していない為であろう。従つて, TSH $10^{-2}-10^{-3}-10^{-4}$ J.S.U. 亿於て, TSH 濃度と peroxidase 活性測定值との間に，直線関係の成立するのも当然である.

次に, 反応溶液の paperchromatography による成績の検討であるが, 著者の実験では, 反応終了後の溶 液中に monoiodotyrosine, diiodotyrosine を証明した。

処が，標品 peroxidase を使用した場合の反応溶液の paperchromatography では，TSH $10^{-2}-10^{-3}$ — $10^{-4}$ J.S.U. の順に monoiodotyrosine, diiodotyrosine の生成量の減少するのを認め, 又, 添加したtyrosine 
の量は, monoiodotyrosine, diiodotyrosine の量に反比例して減少しているのを見たが，てれは Warburg 検圧計を用いて peroxidase 活性值の測定を行つた際, TSH $10^{-2}-10^{-3}-10^{-4}$ J.S.U. の順に peroxidase 活 性が低下すると云う実験成績と一致する。即ち，TSH $10^{-2}$ J.S.U. で peroxidase 活性が最も賦活され，同 時に沃度アミノ酸の生成も，最も著明に行われる事を示している。

これに対し，雄モルモット甲状腺 homogenate を用いた場合にも， monoiodotyrosine, diiodotyrosine の生成を認めた. 此の場合, 標品 peroxidase を用いた場合より, monoiodotyrosine, diiodotyrosine の生 成量の少いのは, peroxidase の絶対量の少い事によるもので, gasmetry での成績とも一致する，更に又， 甲状腺 homogenate に存在する deiodinase 等の干渉も，てれに関与するものと考えられる。乙の点に関 して，1951年，Roche ${ }^{29) 30)}$ は， deiodinase は甲状腺での活性が特に高く，しかも TSH により賦活される 事を明らかにしているが，此の事実から，反応系に添加したTSH によつて賦活された deiodinase が，一 旦生成された沃度アミノ酸を脱沃度化する事も予想される。以上の実験結果よりみて，TSH によつて賦活 された peroxidase が沃度酸化を促進し, 生成された沃度分子は tyrosine と結合して, monoiodotyrosine. 及び diiodotyroiine が生成されたものと著者は理解するが，而し，沃度アミノ酸の生成には，非酵素的酸 化が起り得ると云う可能性も否定出来ない，そこで酵素源である標品 peroxidase 又は甲状腺 homogenate を反応系に添加せず，他は総て前述の条件で操作した後, 反応溶液を paperchromatography で展開した 所, 全然沃度アミノ酸の生成を見なかつた。此の結果から沃度アミノ酸の生成に関しては，ての実験条件で は, 非酵素的酸化は否定し得る. 従つて, 甲状腺沃度代謝に peroxidase が必須であるとする著者の説が正 しいと云える。

処で，甲状腺 peroxidase が，甲状腺に於ける沃度代謝のどの過程に，如何に関与するかについては種々 の説がある。此のうち, 第 1 段階である沃度酸化過程に関与する事は, Dempsey ${ }^{8}$ (1944), Keston ${ }^{31)}$ (1944), Haley $^{32)}$ (1955), Wyngarden ${ }^{33)}$ (1955), Alexander ${ }^{11) 34)}$ (1959, 1961), De Groot \&. Davis (1960, 1961, 1962) 12)35)36)37)等によつて明らかにされている. 第 2 段階である沃化過程への関与については, 諸説があつて一致 していない. 即ち, De Groot ${ }^{37}$ は非酵素的に進行すると述べ, Klebanoff ${ }^{28}$ は, 酸化段階と同じく peroxidase により触媒されるか, 又は，非酵素的に行われると主張し，又，Fawcett，Kirkwood ${ }^{38)}$ (1953) の如く，特 異性のある tyrosine iodinase の存在を唱える人もある. 更に, Westerfeld \& Lowe ${ }^{39)}$ (1942) は, 次の段 階たる thyroxine の酸化的縮合に, peroxidase が関与すると述べている。而し，少くとも上述した実験結 果からみて，TSH が peroxidase を直接賦活する事により，沃度酸化が促進され，更に沃化段階も促進され， その結果，沃度アミノ酸の生成量も増加するものと著者は考える。广お tyrosine iodinase 等の含有され ていない標品 peroxidase を使用した場合にも, monoiodotyrosine, diiodotyrosine, の生ずる事から, 沃化 段階にも酸化段階と同じく, peroxidase が関与する可能性もあり, 又, 他方沃化過程が非酵素的に行われ る可能性もあるとする Klebanoff ${ }^{28)}$ の所説が妥当である. 併し, 此 2 つの可能性の何れが真であるかは, 本 研究の範囲外である.

\section{結 論}

前章に詳述した peroxidase 活性測定法の基質に, TSH を添加して, peroxidase に対する TSH の影響 を, manometric に検討すると共に，反応後の基質を paperchromatography で展開して，その生成物を分 析した結果，次の事実を明らかにした。

1) TSH は，直接的に peroxidase 活性を促進するものと思われる.

2 ）標品 peroxidase を用いた場合でも，モルモット甲状腺 homogenate を用いた場合でも，TSH $10^{-2}$ $10^{-3}-10^{-4}$ J.S.U. で同様に賦活される事実から, 沃度酸化に於て, 植物性 peroxidase, 動物性 peroxidase 共に特異性は認められない。

3 ) TSH の濃度 $10^{-2}-10^{-3}-10^{-4}$ J.S.U. の範囲では, TSH 濃度と peroxiease 活性值の上昇率との間 にほほぼ直線関係のある事を認めた。 
4) 反応溶液の paperchromatography で標品 peroxidase を用いた場合には，TSH $10^{-2}$ J.S.U. で monoiodotyrosine, diiodotyrosine, の生成量が最も多く, TSH $10^{-2}, 10^{-3}, 10^{-4}$ J.S.U の順に，てれらの 沃度アミノ酸生成量の減少するのを認めた。雄モルモット甲状腺 homogenate でも, monoiodotyrosine, diiodotyrosine, の生成を認めた。

5 ) 沃度代謝に於て，TSH が peroxidase を賦活する事により，沃度酸化が促進され，更に沃化段階も 促進される結果, 沃度アミノ酸の生成が増加するものと思われる。

本論文の要旨は, 第 9 回日本内分泌学会西日本地方会, 及び第 35 回日本内分泌学会総会に於て発表した.

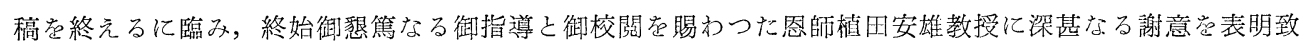
します。尚本研究に御協力戴いた竹内医学士に衰心より謝意袁表すると共に, 御援助戴いた望月医学博士に 感謝致します。

\section{文献}

1) SGHÖNBEIN, G.F. : Verhandl. Naturforsch. Ges., Basel, $1: 339$ (1855)

2) LINOSSIER, M.G. : Compt. rend. biol. soc., $50: 381$ (1898) $\quad$ 3) RAUNDNITZ, R. : Zenter. Physiol., 12 : 790 (1899) 4) LOEW, O. : U.S. Dept. Agric. Rep., No. $8: 47$ (1901) 5) WILLSTÄTTER, R. : A.Stoll : Ann., $416: 21$ (1918) $\quad$ 6) THEORELL, H. : Enzymol., $10: 250$ (1942) 7) AGNER, K. : Acta. Physiol. Scand., 2, Suppl. 8 (1941) $\quad$ 8) DEMPSEY, E.W. : Endocrinology, $34: 27$ (1944) 9) DeROBERTIS, E. and GRASSO, R. : Endocrinology, $38: 137$ (1946) 10) ROSENBERG, I.N. : Science, $116: 503$ (1952) 11) ALEXANDER, N.M. : J.B.C., 234 : 1530 (1959) 12) DeGROOT, L.J. and DAVIS, A.M. : J.B.G., $236: 2009$ (1961) 13) 近藤金 助, 雄田雄平 : 京大食研報, No. $4: 12$ (1951) $\quad$ 14) ETTORI, J. : Biochem J., $44: 35$ (1949) 15) RANDALL, L.O. : J.B.G., $164: 521$ (1946) 16) BERGMANN, A.J. and TURNER, G.W. : Endocrinology, 24:656 (1939) 17) 望月真人：日本内分泌学会雑誌, 第36巻 : 第 4 号, 668 (昭 35) 18) LEBLOND, G.P. \& SÜE, P. : Amer. J. Physiol., 134, 549 (1941) 19) MORTON, M.E. et al. : J.B.C., 140, 603 (1941) 20) KEATING, F.R. et al. : Endocrinology. $36: 137$ (1945) 21) RAWSON, R.W. \& MONEY, W.L. : Recent Prog. Hormone Res. 4 : 397 (1949) 22) Olin-LAMBERG, G. \& LAMBERG, B.A. : Acta Endocrinol., $14: 83$ (1953) 23) STANLEY, M.M. \& ASTWOOD, E.B. : Endocrinology, $44: 49$ (1949) 24) 鈴木光雄 : 日本内分泌 学会雑誌, 第38巻, 第 3 号, 288 (昭37) 25$)$ KLEBANOFF, S.J. : J.B.G., $234: 2437$ (1959) 26) KLEBANOFF, S. : J. : Bioch. Biophy. acta, $48: 93$ (1961) 27) KLEBANOFF, S.J. : Bioch. Biophy. acta, $56: 460$ (1962) 28) KLEBANOFF, S.J. : Bioch. Biophy. acta, $58: 563$ (1962) 29) ROCHE, J. et al. : C.r. Soc. Biol., $145: 288$ (1952) 30 ROCHE, J. et al. : G.r. Soc. Biol. $147: 234$ (1954) 31) KESTON, A.S. : J.B.C., $153: 335$ (1944) 32) HALEY, H.L. : Arch. Path., $59: 635$ (1955) 33) WYNGARDEN, J.B. : J.B.G., $212: 151$ (1955) 34) ALEXANDER. N.M. : Endocrinology, $68: 671$ (1961) $\quad 35)$ DeGROOT, L.J. : J.B.C., 235 : 1390 (1960 36 DeGROOT, L.J, : J.B.G., $70: 505$ (1962) 37) DeGROOT, L.J. : Endocrinology, $70: 492$ (1962) 38) FAWGETT, D.M. \& KIRKWOOD, S. : J.B.C. $205: 795$ (1953) W9) WESTERFELD, W.W. and LOWE, G. : J.B.G., $145: 463$ (1942) 